\title{
The spatial signature of an Insula neighbourhood of Roman Ostia
}

Ostia, the harbour city of ancient Rome, is one of the few archaeological sites where the extensive architectural remains allow us to explore the complexity of Roman urban life. Although the site has been attracting widespread research interest, until recently the city's spatial organisation remained a neglected field of study, with only limited attention given to systematic spatial analysis. This chapter concentrates on Ostia's spatial organisation to explore how social processes map into built form, and it applies Space Syntax methods to address questions related to urban development during the second and early third centuries AD. This chapter offers a further context for Space Syntax analysis, detailed applications of which can also be seen in Fisher's, Letesson's and Van Nes' chapters in this volume, while Hillier's chapter provides the theoretical underpinning of Space Syntax and discusses methodological questions.

Space Syntax has been successfully employed in archaeological studies and has helped to redress a conceptual imbalance in archaeological research wherein the highly dynamic space of past urban landscapes has remained predominantly studied from a static position. Space Syntax allows us to pursue methods for the reconstruction of past movement and interaction, employing techniques of analysis that are configurational, dynamic and experiential. This chapter presents and discusses the results of Space Syntax analyses applied to an urban neighbourhood, Insula IV ii, one of Ostia's city street blocks (Stöger 2007; 20II). The topics covered include the spatial organisation of the 'insula neighbourhood' and the integrative potential of shared activities areas within the Insula (cf. Vaughan et al. 2009 on today's suburban activity centres).

\section{The spatial organisation of Insula IV ii}

Since Ostia's insulae (city blocks) came to light in the large-scale excavations of the late I930s/early I940s, they have been widely studied, extending from architectural studies (Boersma I985; Bauers I999) to attempts claiming ideological continuity between Roman imperial and Italian fascist architecture (on Calza's influence cf. Kockel 200I, p. 67-72). Earlier work concentrated on typological and cultural-historical explanations (Packer I97I; Pasini I978), whereas more recent approaches follow advances made in Pompeian studies, partially integrating concepts of today's urban planning and urban geography into archaeological research (Laurence 2007; Jones and Robinson 2007; Ynnilä 20II). With reference to Ostia, these studies incorporate aspects of the insulae's spatial organisation into research 
deploying a wider social focus relating to status and ownership (DeLaine I999; 2004; Gering 2002). Other current approaches examine the infrastructural capacity of insulae and value their ability to adapt to dynamic urban processes (Scagliarini Corlàita I995; Steuernagel 200I); others in turn view particular insulae as short-lived material manifestations of architectural dreams, only to be rapidly modified in response to demographic and economic change (Gering 2002).

The current insula discussion forms part of a wider discourse on Roman neighbourhoods (Bert Lott 2004) and links up with a comparative archaeological study on neighbourhoods in ancient cities (Smith 20I0); Space Syntax methods of spatial analysis add a new perspective to the ongoing discussion, while general trends and problems in the archaeological application of Space Syntax have been discussed thoroughly in several studies (e.g. Thaler 2005, p. 324-326; Cutting 2003). Space Syntax techniques not only provide evidence for the intricate organisation of space within the insulae, but also investigate the active role of spatial characteristics. According to Space Syntax theory the spatial structure of the built environment embodies knowledge of social relations (Hillier and Hanson I984, p. I84-I85), whereby space not only assumes a physical location but encodes, communicates and reproduces social meaning (Fisher 2006, p. I24). Insula IV ii serves as a case study, while several other Ostian insulae equally warrant a detailed spatial analysis. Still, Insula IV ii is of particular interest, since a number of spatial features consisting of interlinked courtyards make Insula IV ii a very appealing dataset for spatial analysis. A better understanding of the Insula's spatial organisation might allow us to gain insights into the Insula as a lived space.

The Space Syntax analysis builds on an archaeological assessment of the Insula's architectural remains by the author conducted earlier (Stöger 20II, p. 67-I58). From this thorough study it was possible to establish that all extant buildings were in use during the early $3^{\text {rd }}$ century AD, forming a simultaneously existing spatial association, which is a crucial requirement for spatial analysis. Earliest levels of occupation have been dated to the Late Republican and Early Imperial periods, while the Insula enjoyed a long period of use, lasting until the $4^{\text {th }} / 5^{\text {th }}$ centuries AD. Selecting the early $3^{\text {rd }}$ century as a time-slice for analysis places the spatial discussion within two major urban developments: on the one hand Ostia's $2^{\text {nd }}$ century AD urban expansion, which is widely understood as a 'boom-town' phenomenon (Heinzelmann 2002; 2005), and on the other hand Ostia's changing role during the early $3^{\text {rd }}$ century, which saw a transformation from a commercial hub with an outward focus to a 'consumer' city responding to the needs of an increasingly local clientele (Pavolini 2002; Gering 2004, p. 303).

In the following section the Insula's spatial structure will be examined. The first part describes the spatial characteristics which are readily apparent. Next, the Insula's topological and visual patterns are analysed and their spatial relations calculated, using Space Syntax methods; this forms the main part of the analytical approach to the Insula's spatial structure. Finally, a summary of the Insula's spatial organisation will be presented, together 
with an evaluation of how it relates to the human use of space and how the Insula functioned as an urban neighbourhood. This will lead to another set of questions related to the position of the Insula within the spatial configuration of the entire city, of which the Insula is a member, as much as it is a unique and distinguishable entity.

\section{Insula IVii: location and description}

Located on the southern cardo maximus, near the Porta Laurentina, but still inside the Late Republican city walls, Insula IV ii enjoyed a position that benefited from the relative proximity to the city centre, as well as from the closeness to the city gate with its connection to the extra-mural areas of Ostia and beyond. Placed at the intersection between the cardo and the Via della Caupona, a side road south off the cardo, the Insula appears well positioned within the urban street network (fig. I). Towards the east the Insula is delimited by the triangular area of the Campo della Magna Mater, one of Ostia's main sanctuaries, dedicated to Cybele, the great mother goddess. The Insula covers a total area of $732 \mathrm{I} \mathrm{m}^{2}$ comprising I4 buildings, characterised by diverse land-uses (fig. 2): it represents a built environment that potentially accommodated commercial (shops and storage), industrial (workshops and small scale production), recreational (baths and inns), sacred (mithraeum), and communal (open courtyards, entrance passages and portico), as well as habitation space (ground floor and upstairs dwellings) within its confines. These spaces were not only linked functionally, but also through a spatial relationship provided by shared common courtyards.

A number of the Insula's spatial characteristics are readily apparent: commercial space was predominantly located along the street fronts, maximising the potential for interaction at the Insula's interface with public space. Industrial space in contrast reached deeper into the Insula, with the narrow end of the plot along the street front. The southernmost corner of the Insula, the area least accessible, was dedicated to the Mitreo degli animali, a cult room serving a limited number of members devoted to the cult of Mithras. Several buildings provided dwelling units at ground floor level, while the majority of habitation spaces were located on the upper floors. The diversity of land-use might have allowed the residents to remain within the boundary of the Insula for most day-to-day activities, while the generously proportioned internal courtyards could have functioned as common areas. The spaciousness of the open areas, which cover about $20 \%$ of the Insula's total terrain, points not only to a generous attitude towards space, but also indicates that numerous activities could have taken place simultaneously within the courtyards. 


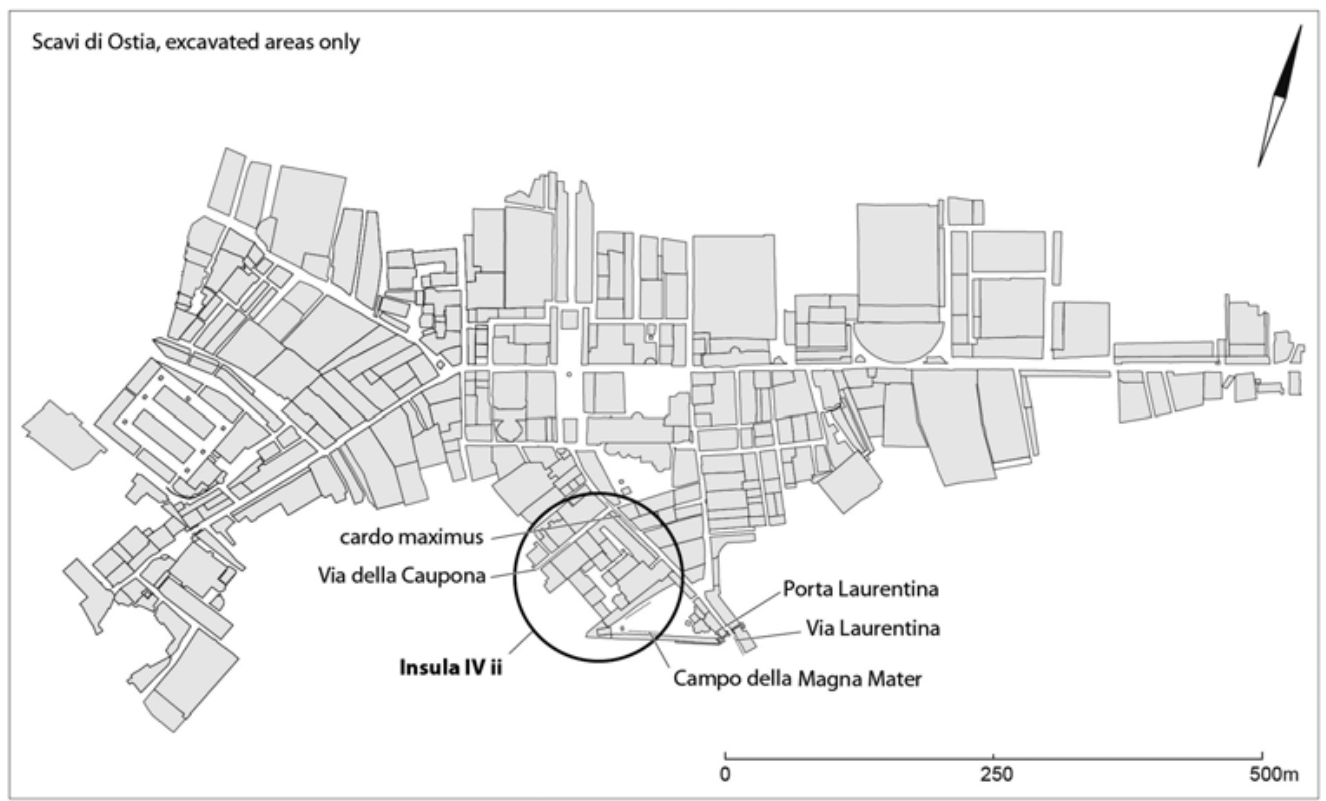

Figure 1 | Insula IV ii located adjacent to the Campo della Magna Mater.

\section{A three-way Space Syntax approach to Insula IV ii}

The Space Syntax analyses applied to the Insula follow the three-way approach suggested by Hanson (I998, p. 38). Hanson recommends that space should be examined through its three principal aspects: its axial or one-dimensional structure (lines of movement), its convex or two-dimensional organisation (convex spaces such as rooms and buildings) and its visual fields. The three-way approach assures that each type of analysis relates to one aspect of how inhabitants and visitors experienced and used space. Accordingly, the appropriate Space Syntax tools have been applied to the Insula's past built spaces: axial analysis, convex or access analysis and visibility graph analysis (VGA) or isovists (on isovists and visibility graph analysis see Turner et al. (200I), on the theoretical underpinning of Space Syntax analyses see Hillier and Hanson (I984, p. I43-I75). The Space Syntax methods have been well explained elsewhere in studies of Pompeian houses and Ostia's medianum apartments (Grahame 2000, p. 24-36; DeLaine 2004, p. 157-I58). The method therefore requires little comment. All buildings within the Insula have been analysed twice, individually and collectively, forming the Insula's total configuration. Only a small section of the analysis will be reproduced here, concentrating on the Insula's total spatial configuration, examined as a single spatial entity. This should allow us to achieve a better understanding of the functioning of the Insula's collective spatial structure, and will help us to establish to what extent the individual buildings were affected by the larger spatial entity. 


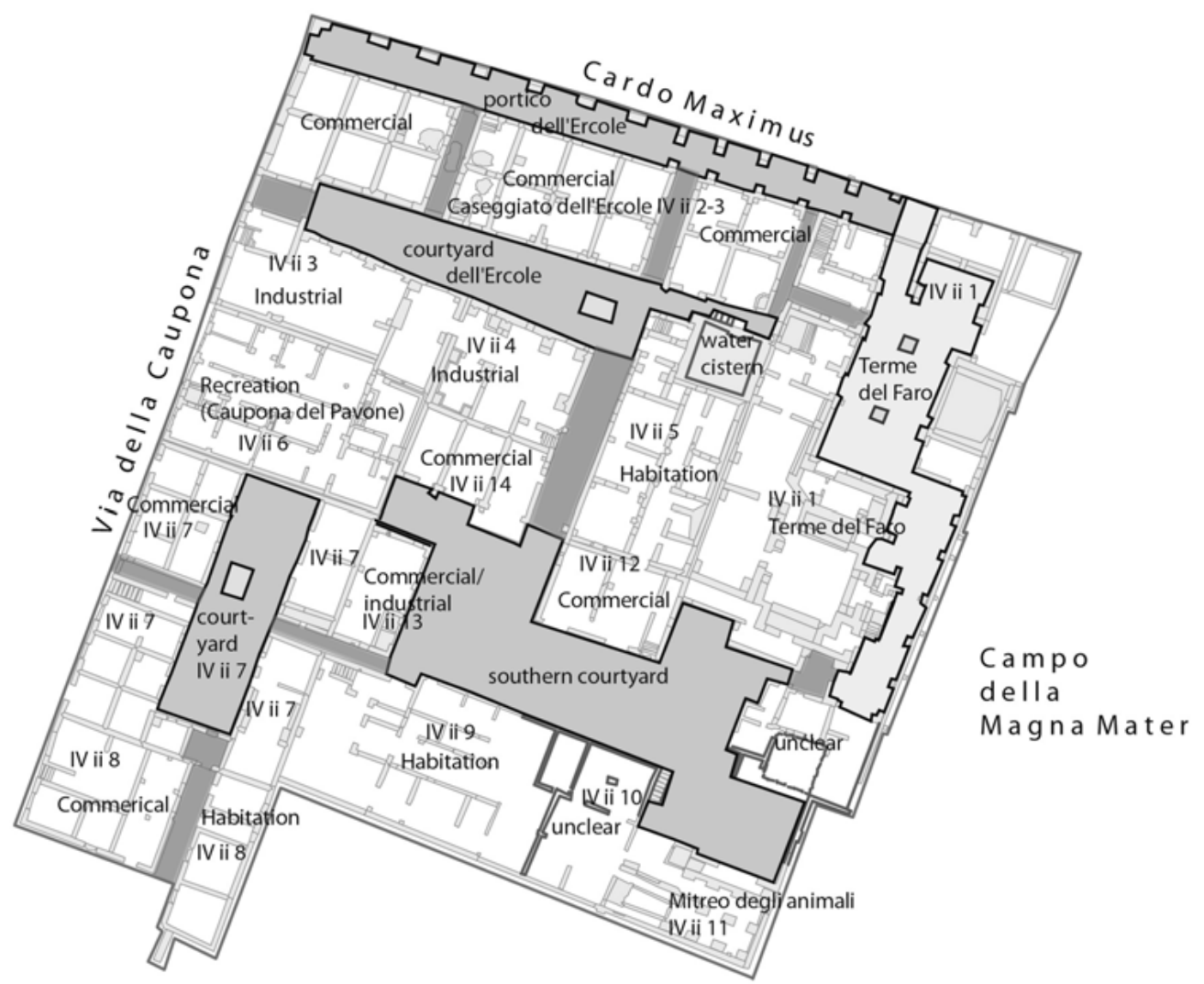

Figure 2 | Insula IV ii comprises I4 buildings with a variety of land-uses: commercial, industrial, recreational (baths and inns), as well as habitation and cultic use (mithraeum).

The Insula consists of I4 individual buildings (fig. 2), which constitute a total of I84 individual spaces, including the outside carrier space, Ostia's street network, counting as one space. Of particular interest are the 'commons', the internal courtyards and passages, which were held in shared use by all buildings within the Insula. These spaces acted as major integrators and distributors, leading movement into and within the Insula, and were essential for providing access to those buildings which were not connected to the exterior public carrier space.

\section{Insula IV $\mathrm{ii}$ - a reading from access maps and spatial values}

Access analysis is a promising starting point for most syntactical analyses (Hillier and Hanson 1984; Hanson 1998; Grahame 2000, p. 29-36). Applied to the Insula's total ground plan, a graph structure (j-graph) was produced, justified with respect to the outside space 


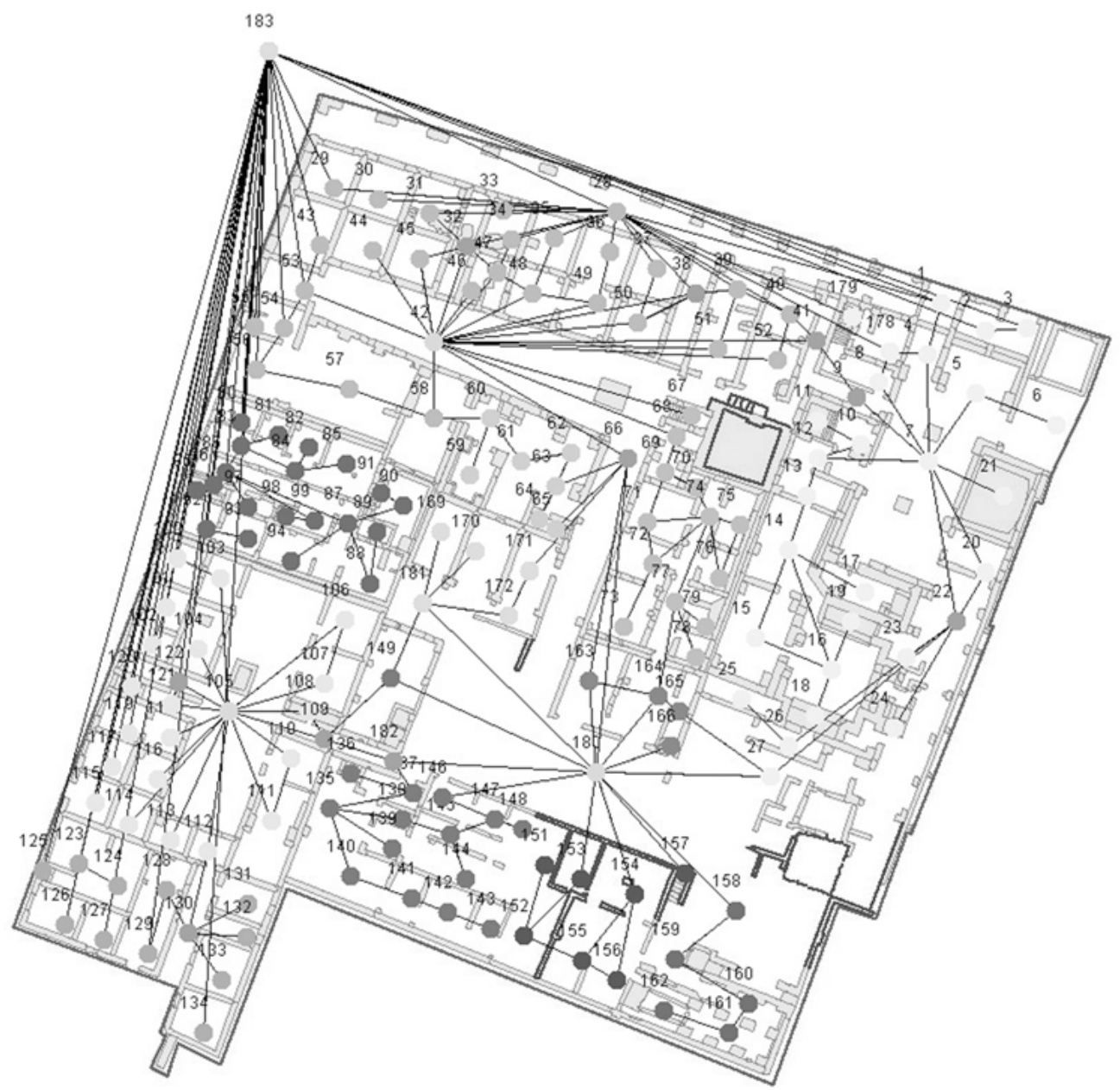

Figure 3 | Insula IV ii, topological graph of the total configuration (I83 = outside carrier; 42 , I05 and $\mathrm{I} 8 \mathrm{O}=$ courtyards, $28=$ portico) .

(fig. 3). The graph is a visual representation of the topological connections between all spaces (rooms and open spaces) and enables us to calculate spatial values (control values and RRA, Real Relative Asymmetry) for comparative quantitative assessment. Control values concern a space and its immediate neighbouring spaces (local), while RRA deals with a certain space and its relationship to all other spaces within the system (global). These measures respond to the Insula's local and global properties and help in assessing the potential of different spaces for interaction between residents and visitors.

The Insula's graph structure can be best described as a broad multiple-entry graph with 28 spaces connected to the outside space, with a total of ro depth-steps, measured from the outside carrier to the topologically most remote spaces. The mean integration 
value (MRRA) for the total graph is 0.937 , pointing to a moderately well integrated spatial structure. Mean integration values allow a first hand impression, as they indicate on average how shallow or deep the spaces in the Insula are from one another. This allows us to formulate ideas about the use of space and the potential function of buildings and rooms. A comparison with the mean integration values for the Insula's most integrated building, the Caseggiato dell'Ercole (MRRA 0.562) and the least integrated building, the Mitreo degli animali (MRRA I.893), helps us to gain a better perspective of the total structure.

The analytical strategy chosen was to identify the potential 'hotspots' for interaction within the Insula's spatial configuration. From the total configuration (fig. 4) a number of spaces emerge as the areas with the highest levels of integration and control potential. Interesting insights can be gained by correlating the controlling spaces, indicated by control values in excess of I (Grahame 2000, p. 33-34), with those spaces with very low RRA values. These range from zero to infinite - the higher the RRA value the more inaccessible a space will be; hence spaces with high levels of global integration are indicated by low RRA (see Grahame 2000, p. 35, 46). The area in which we find the highest consistency between local and global integration potential might point to those spaces by which the Insula was functionally defined (cf. table I). Within the total configuration these spaces are most notably dedicated to movement and interaction, forming the Insula's interface with visitors: portico 28 and courtyard 42 of the Caseggiato dell'Ercole, as well as the outside carrier space I83. Together with the inner courtyards, I05 and I80, these spaces provide the Insula's principal circulation system.

It is worth noting that all spaces which serve a common use are located in the shallower, well integrated parts of the Insula, relatively close to the outside space, mostly i to 2 step-depths, but not more than 4 step-depths away from the outside carrier space. In contrast, all spaces which are residential or more private in nature are located in the deeper, less integrated portion of the Insula, at 5 to Io depth-steps away from the public outside space. This suggests that through its collective structure the Insula was able to generate one feature common to most types of domestic architecture: it incorporates the elementary relation between the inhabitant/resident and the visitor (Hillier and Hanson I984, p. I83-I84). This means that the inhabitant is in the deeper, often less integrated, parts and interfaces with the visitor through the shallower, often well-integrated parts of the Insula. If we take this observation a step further we might be able to suggest that at the collective level the Insula still upheld an inherently domestic structure, while at an individual level a number of buildings had lost their elementary inhabitant/visitor dynamic. This observation seems to receive even more significance when considered within the wider context of the Insula's evolving configuration. In the course of its development the Insula experienced the loss of the domus, which constituted the standard domestic building and served as the urban 'base-unit', at least until the earlier Trajanic period (c. Ioo AD). Collectively, however, the Insula seems to have retained some characteristics reminiscent of domus architecture, such as inner courtyards and a structured access to public space. 


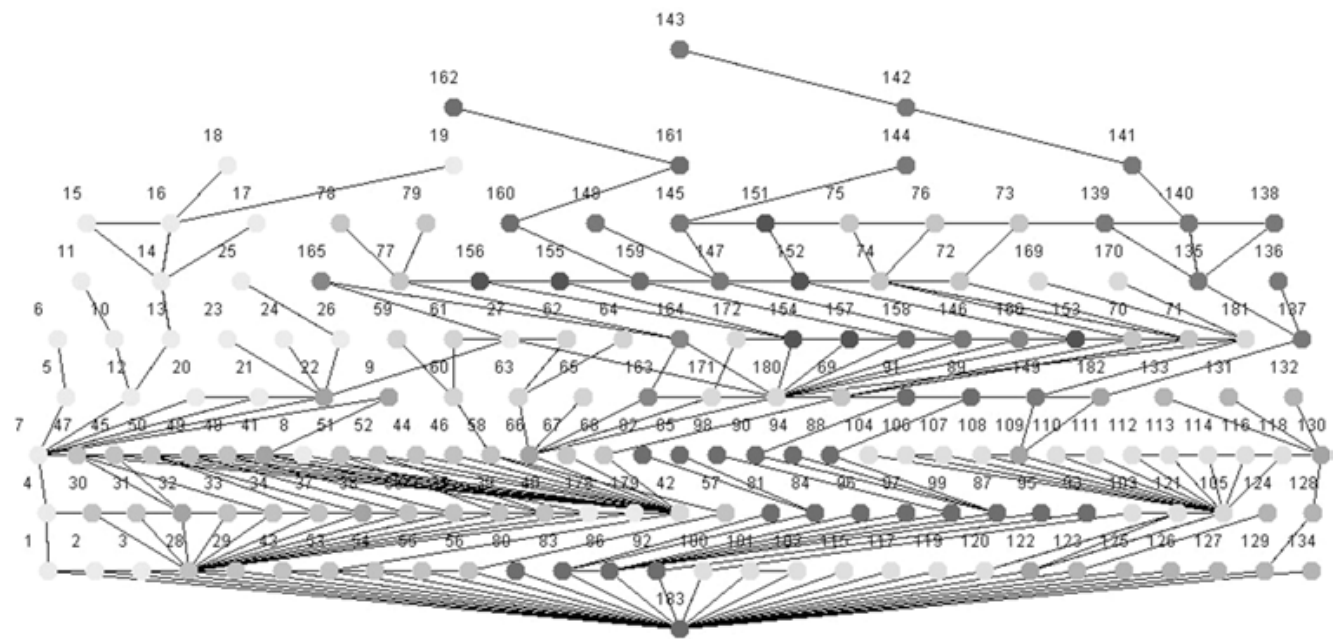

Figure 4 | J-graph Insula IV ii represents the topological relationship between all spaces within the Insula, calculated from the outside space (root $183=$ outside carrier).

Table 1 | The Insula's 'hotspots': the circulation spaces with highest levels of local and global integration potential (RRA 500-650 = high, 650-950 = moderate, $950+=$ low).

\begin{tabular}{|l|l|l|l|l|l|l|l|l|}
\hline Building & $\begin{array}{l}\text { Room/ } \\
\text { function }\end{array}$ & No. & Depth & $\begin{array}{l}\text { RRA } \\
\text { (MRRA } \\
\text { o.937) }\end{array}$ & $\begin{array}{l}\text { Global } \\
\text { interaction } \\
\text { potential }\end{array}$ & $\begin{array}{l}\text { Local } \\
\text { interaction } \\
\text { potential }\end{array}$ & $\begin{array}{l}\text { Control } \\
\text { Values }\end{array}$ & $\begin{array}{l}\text { Potential } \\
\text { presence } \\
\text { availability }\end{array}$ \\
\hline IV ii 2 & Portico & 28 & I.0 & 0.622 & High & High & 7.652 & High \\
\hline IV ii 3 & Courtyard & 42 & 2.0 & 0.558 & High & High & 7.699 & High \\
\hline IV ii 6 & Corridor & 86 & I.0 & 0.733 & Moderate & Moderate & 4.035 & Moderate \\
\hline IV ii 7 & Courtyard & I05 & 2.0 & 0.703 & Moderate & High & 9.416 & Mod/High \\
\hline common & $\begin{array}{l}\text { Southern } \\
\text { courtyard }\end{array}$ & I80 & 4.0 & 0.617 & High & High & 5.783 & High \\
\hline common & $\begin{array}{l}\text { Outside } \\
\text { carrier }\end{array}$ & I83 & 0.0 & 0.562 & High & High & I65.386 & High \\
\hline
\end{tabular}

Next to the Insula's most integrated spaces, the most segregated spaces are equally instructive about the functioning of the configuration (see table 2). As listed in table 2 below, the Terme del Faro's heated pools, I8 and I9, rank very high on the list of the most segregated spaces within the Insula. The heated pools are located eight depth-steps away from the outside space and can only be reached after a sequence of rooms has been crossed; their secluded position seems related to their function and affords higher levels of privacy than other rooms. Two other rooms come into view from the assessment of the collective structure: I43 and I62. Unsurprisingly, the mithraeum's cult room I62 emerges as one of the 
Table 2 | The Insula's most segregated spaces with lowest global and local interaction potential.

\begin{tabular}{|l|l|l|l|l|l|l|l|l|}
\hline Building & $\begin{array}{l}\text { Room } \\
\text { function }\end{array}$ & No. & Depth & $\begin{array}{l}\text { RRA } \\
\text { (MRRA } \\
\text { 0.937) }\end{array}$ & $\begin{array}{l}\text { Global } \\
\text { interaction } \\
\text { potential }\end{array}$ & $\begin{array}{l}\text { Local } \\
\text { interaction } \\
\text { potential }\end{array}$ & $\begin{array}{l}\text { Control } \\
\text { Values }\end{array}$ & $\begin{array}{l}\text { Potential } \\
\text { Presence } \\
\text { availability }\end{array}$ \\
\hline IV ii I & $\begin{array}{l}\text { Heated } \\
\text { pool }\end{array}$ & I8 & 8.0 & I.693 & Low & Low & 0.250 & Low \\
\hline IV ii I & $\begin{array}{l}\text { Heated } \\
\text { pool }\end{array}$ & I9 & 8.0 & I.693 & Low & Low & 0.250 & Low \\
\hline IV ii 9 & Room & I43 & I0.0 & I.85I & Low & Low & 0.500 & Low \\
\hline IV ii II & $\begin{array}{l}\text { Cult } \\
\text { room }\end{array}$ & I62 & 9.0 & I.605 & Low & Low & 0.500 & Low \\
\hline
\end{tabular}

most segregated rooms within the entire Insula, superseded only by room I43, which is part of Building IVii 9. Room I43 ranks as the most segregated space of the total configuration. It belongs to a range of rooms including I4I, I42 and I43. The group is noteworthy since it seems to form a medianum apartment located at the Insula's southernmost edge. Medianum apartments usually consist of ranges of rooms grouped around a hall or wide corridor (see DeLaine 2004 for a syntactic assessment of Ostia's medianum apartments). Facing south, unobstructed by direct neighbours, this range of rooms must have provided an excellent dwelling-unit, appealing to the upper end of the rental market. Its secluded location might have even enhanced the value of the apartment, since its 'remoteness' provided higher levels of privacy than any other ground floor dwelling available within the Insula.

The inner courtyards (42, I80 and I05) play a significant role in channelling movement within the Insula. The southern courtyard $\mathrm{I} 8 \mathrm{O}$ is the only one directly connected to all other courts by means of passage corridors. The presence of three courtyards could potentially create a sense of fragmentation within the Insula; this seems, however, balanced by the fact that the southern courtyard acted as a centre for the entire layout. Moreover, the different route options offered by the various passages and courtyards might have helped in counteracting disintegration, since the routes unite the Insula through movement. The wide range of movement choices enabled those who used the Insula, both residents and visitors, to explore the spaces in different ways, generating routes according to specific functional requirements, or simply to stroll through the Insula and go wherever their fancy might take them. One circulation path is of particular interest, since it completely encircled the baths and their associated buildings without passing through outside space, and could therefore run independently of visitor relations. The loop interconnects the baths with the southern courtyard, leading back again into the baths through the central passage and the eastern part of the Caseggiato dell'Ercole, thereby creating a 'spatial Insula' within the Insula (see fig. 7 below). 


\section{The Insula's axial line structure (axial analysis)}

To examine the dynamics of the Insula's internal space structure and to systematically investigate movement we need to shift away from access analysis and select Space Syntax techniques specifically suited to capture movement. This also requires a shift from built spaces to open spaces, thus moving away from the Insula's buildings to its open courtyards and passages. A careful look at the Insula's internal space structure already shows that it is distinctly broken up into convex spaces (the courtyards), and into lines (entrance corridors and passages), which interlink the convex spaces (fig. 5).

Before homing in on the Insula's linear space structure, a look at Hillier's findings on the City of London's space structure may be helpful for developing a deeper understanding of the Insula's spatial organisation (cf. Hillier 2007, p. III-I37). Hillier identified two constant spatial properties within the small-scale complexes of the City of London which seem to explain how the supposedly labyrinthine back areas of the City proved to be highly intelligible for those who navigated its spaces. The first property relates to the prevailing movement patterns in which he identified a persistent 'two-line-logic' (Hillier 2007, p. II6-II9). In a similar but less intricate way, there is also a 'two-line logic' to movement within the Insula: if one enters the Insula through one of the passage corridors visible from the cardo maximus, the next line will take a visitor either out of the back area by leaving the courtyard through the exit on the Via della Caupona, or further into the Insula to some significant spatial event like the next large courtyard, i.e. the southern courtyard. From there, another line would take visitors out of the Insula again by passing through building IV ii 7 , reaching the Via della Caupona. This means that wherever one goes within the Insula, there is usually a point from which one can see the point of departure, i.e. the entry into the Insula, and where the next point of aim might be. Hillier contends that this spatial technique has the effect that the back areas become normally and naturally used for movement as part of the urban space pattern, and he adds that there is no inhibition or sense of territorial intrusion in these areas (Hillier 2007, p. II6-II8). Whether this holds true for the Insula is difficult to prove, but the ideas are compelling and should be examined in the light of the archaeological evidence, and, above all, put to the test by correlating the Insula's axial line structure and the spatial integration values (RRA) for the courtyards under discussion.

The second spatial property identified by Hillier's study of the City of London concerns how the buildings relate to the open spaces. Hillier observed that almost all buildings opened directly onto the convex spaces (courtyards and squares), and through this practice a close relationship between the residents within the buildings and those outside was created. According to Hillier this kind of direct interfacing engendered a sense of unforced copresence between people carrying out different activities (2007, p. II8). From Hillier's study it becomes clear that interaction potential is dependent upon a two-way relationship between the linear space structure (movement spaces) and the buildings and squares (convex spaces) relating to it. Can we make similar observations within the Insula? When look- 


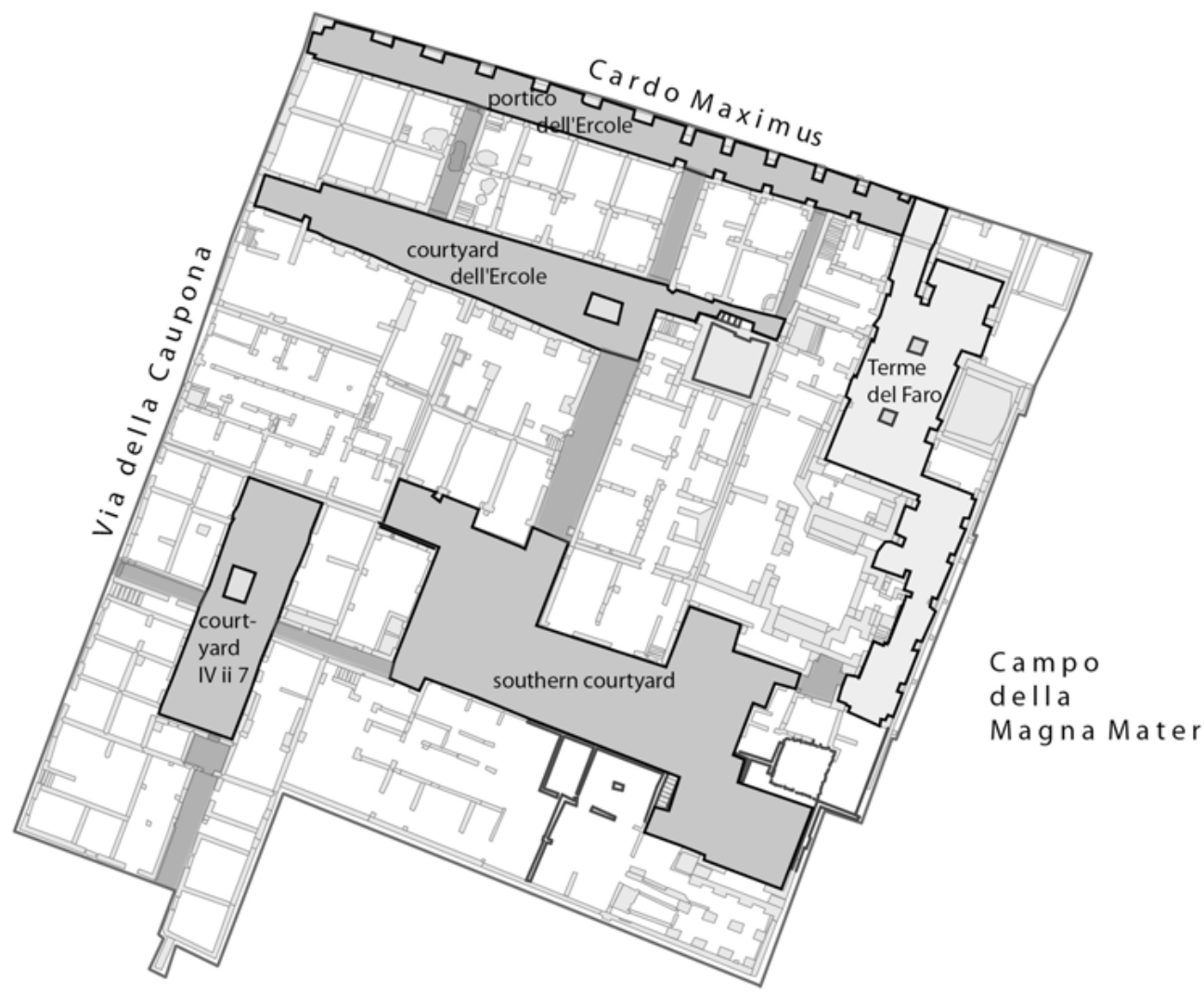

Figure 5 | Insula IVii: courtyards (grey)and passages (darker green) forming axial and convex spaces to serve as the Insula's communication spaces (Terme del Faro in light grey).

ing at the Insula's courtyards we can see that only the southern courtyard was surrounded by individual buildings, while the others were integral parts of buildings (Caseggiato dell'Ercole and Caseggiato IVii 7). The irregular shape of the southern courtyard suggests that it developed through individual negotiations rather than planned design. In line with Hillier's observations it is worth noting that Buildings IVii I2, I3 and I4 open completely onto the courtyard, and hence provide for the interface described by Hillier as being necessary to produce interaction potential. These observations seem supported by the spatial values that have been calculated for the courtyard and the buildings surrounding it (Buildings IV ii Io, I2 and I4 dedicate high levels of integration and control potential to the southern courtyard. Building IVii Io: RRA 0.725/control values I.833; Building IVii I2: RRA $0.725 /$ control values 2.583; Building IVii I4: RRA 0.287 /control values 3.333). Therefore, the next step is to reconstruct the Insula's line structure, which represents the potential route matrix, and to examine whether the integration values for the lines match the high integration values dedicated to the courtyards. 


\section{The Insula's axial and visual structure}

In conformity with Hanson's three-way approach, as discussed above, the Insula's line structure and its visual fields have been examined, using Space Syntax's axial analysis and visibility graph analysis (VGA). ${ }^{\mathrm{H}}$ Both are analysis tools specifically designed to capture movement by linking spatial and visual properties. The analysis identifies the most integrated visual lines, calculated for axial integration on the basis of the longest visual lines. This is a two-step process: first, all lines to all lines are calculated (fig. 6); in a second round the fewest longest lines are extracted from the total set and reduced to a representative minimum of lines. The fewest lines embody the Insula's potential route matrix (fig. 7); the latter identifies the Insula's most likely paths of movement, hierarchically ranked and colour-coded (here represented in greyscales only) according to their level of integration with all other lines within the system. The Insula's most integrated line (represented as a dotted line) extends diagonally from the southern courtyard to the baths. The second most integrated line (dotted line) connects the portico to the southern courtyard. Clearly, the southern courtyard comes into view as the converging zone for visual lines from all directions, marking the courtyard as the prime space for movement and social encounter.

The second most integrated line (dotted line) connects from the portico through to the southern courtyard. This line represents the axial connection between outside public space (cardo maximus) and the very centre of the Insula. The line proves to be consistent and seems to form part of the 'two-line logic' which appears to be a constant component of the Insula's space structure. The line's counterpart is found in the longest axial line, which connects from the Via della Caupona through Building IVii 7 and all across the southern courtyard. These two lines form the Insula's visual base structure, constituting the root of the Insula's 'two-line logic'. Both lines remained preserved and respected throughout the Insula's development. This is evident from the alignment of the buildings, which safeguard the visual lines, even at all costs, as the passage through Buildings IVii 7, 9 and I3 demonstrates. Interestingly, the lines are also respected by more mundane structures such as the fountains located within the courtyards.

A further level of analysis pertaining to the Insula's visual fields has been applied, the visibility graph analysis (VGA). It is based on visual integration and on a positive correlation between visibility and movement potential (Turner et al. 200I; Hillier and Vaughan 2007). The visibility graph reveals the Insula's visually most integrated spaces (fig. 8), displayed in a ranked order from the most to the least visually integrated spaces (the colour-coded results are represented in greyscale) The southern courtyard emerges as the visually most integrated space, marking the area where the longest visual lines converge as the most inte-

I The graphs and analyses were produced with Depthmap 7.I2.ood and developed at the VR centre for Built Environment, Bartlett, University College London. 


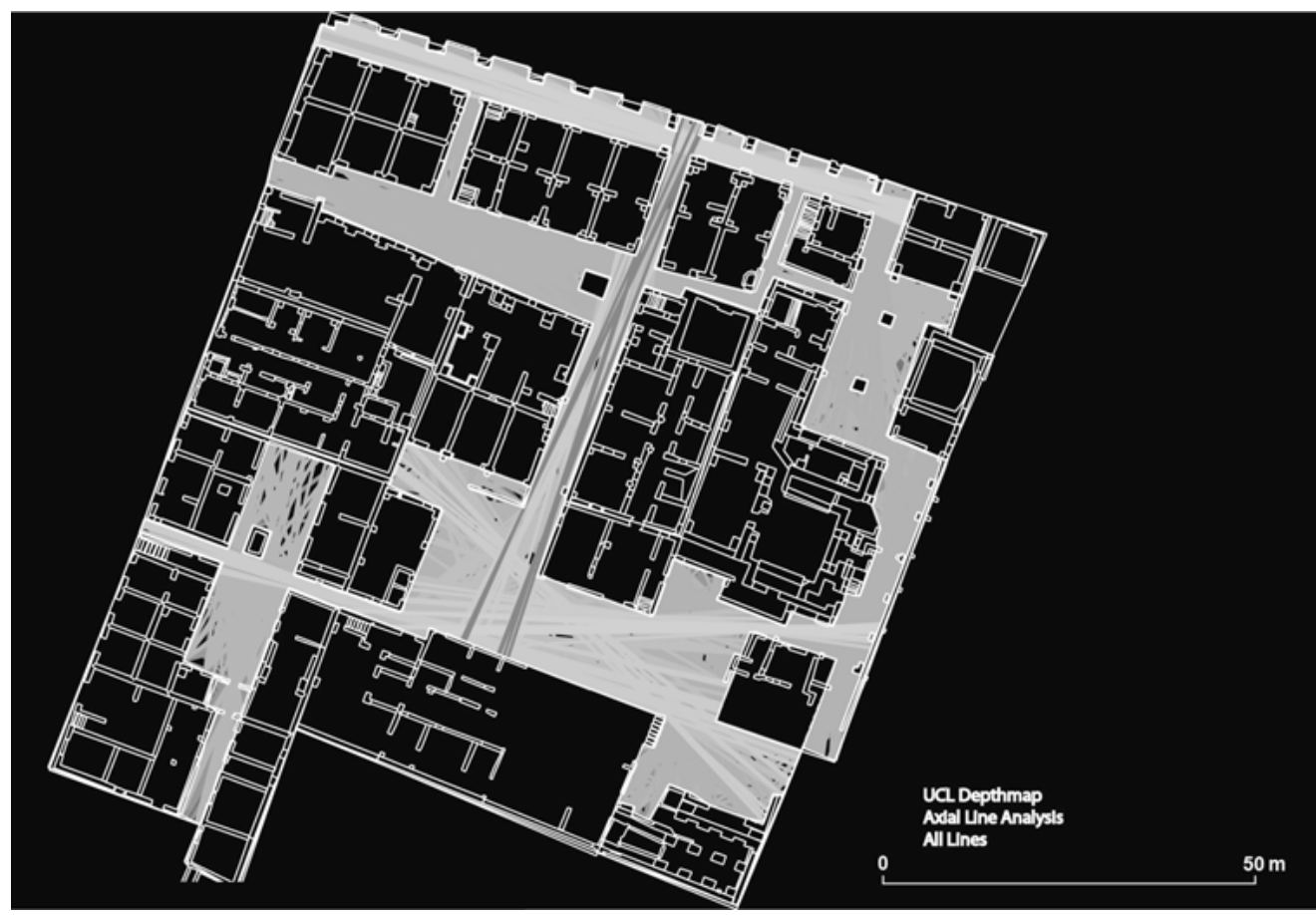

Figure 6 | Insula IVii: internal courtyards, including the movement spaces of the Terme del Faro; axial analysis (all lines) identifies the central passage leading from the portico to the southern courtyard as the visually most integrated space (graphs and analyses produced with Depthmap 7.I2.ood; The Bartlett, University College London).

grated zone (see dotted circle). Hence VGA confirms what was identified by the axial line analysis. Both analyses earmark the southern courtyard as the area where movement coming from various directions within the Insula converged; greater density of movement raises co-presence within the southern courtyard, which is an indication of increased potential for social interaction. Finally, agent-based analysis provided by Depthmap (fig. 9) produced a graph showing the movement traces of 50 autonomous agents walking through the Insula driven by visual parameters only. Their random walks take the majority of the agents to the southern courtyard. Hence once again the southern courtyard emerged as the Insula's best place for social interaction.

\section{Concluding remarks}

In terms of the human use of space the Space Syntax results point to the fact that the Insula was able to draw people in from the street space. However, most importantly, by promoting accessibility to the back part, i.e. the southern courtyard, the Insula's space structure helped 


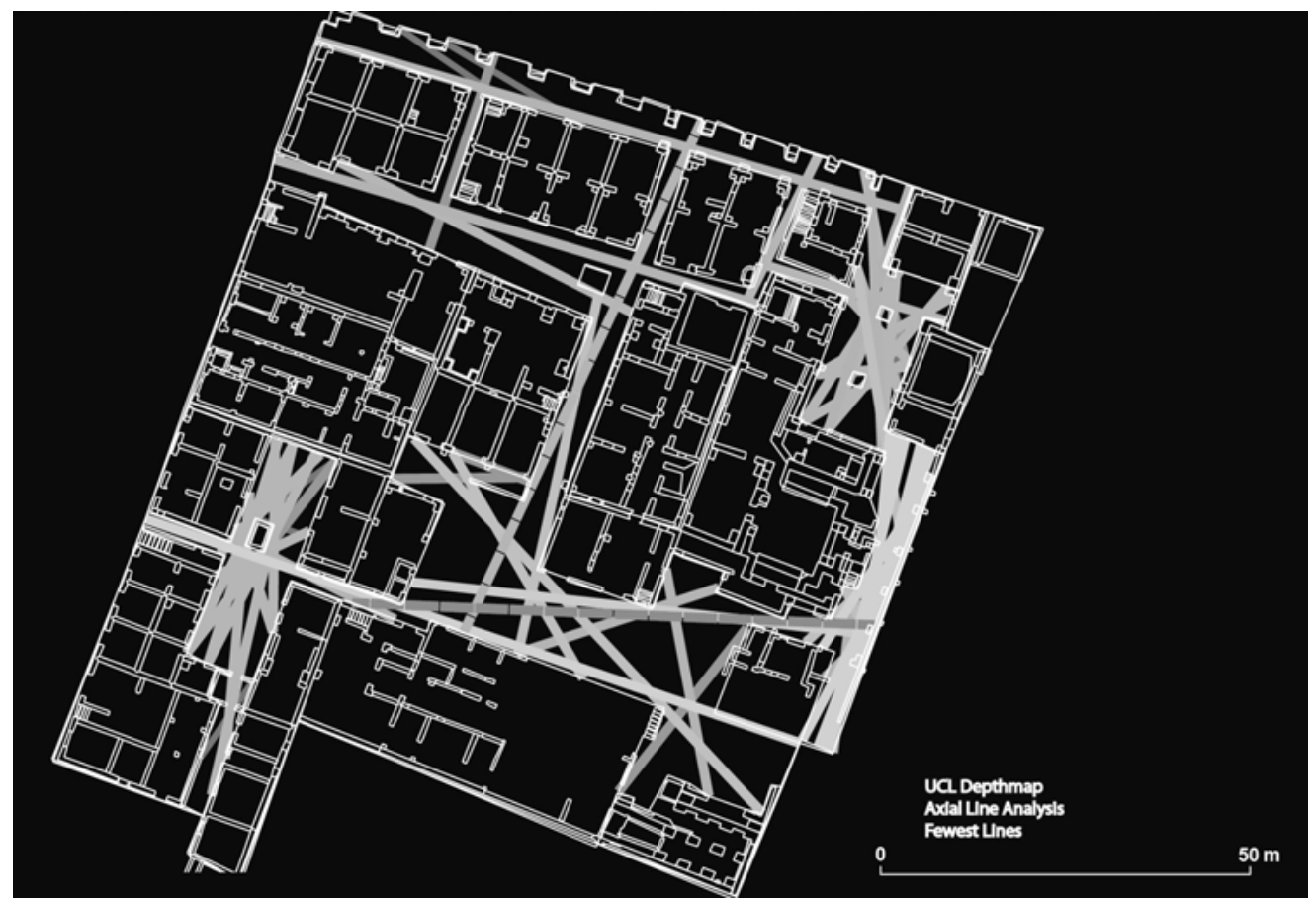

Figure 7| The Insula's potential route matrix based on the longest and fewest lines; represented in greyscales. The movement spaces of the Terme del Faro are included in the analysis (Depthmap 7.I2.ood; The Bartlett, University College London).

in sustaining activities in the back areas. This is even more interesting, since the Insula had clearly defined its commercial front towards the outside through the Caseggiato dell'Ercole, with its portico and a shop front taking up almost the entire length of the Insula along the cardo maximus (cf. Davis 2009, p. 89-104 for buildings with combined commercial and residential uses). As the spatial organisation of the southern courtyard demonstrates, a lively environment of unforced co-presence is not only dependent on the line structure and the open spaces which constitute the movement spaces, but also requires that the buildings relate to the open spaces by opening onto the spaces, and hence interface in a manner to encourage interaction.

With regard to the Insula's quality as lived space, spatial tools were able to make a valuable contribution in showing that space was designed to promote encounter, and to privilege integration over segregation, which ultimately makes for a better and safer neighbourhood, not only in early $3^{\text {rd }}$ century Ostia. The Insula's integrating capacity seems the key to its long period of occupation. Although composed of individual buildings, the Insula's space structure, its courtyards and passages were still essentially collective and shared by the buildings which composed the group. Its collective space structure seems to have prevented fragmentation into highly individualised luxury architecture, which was the fate of 


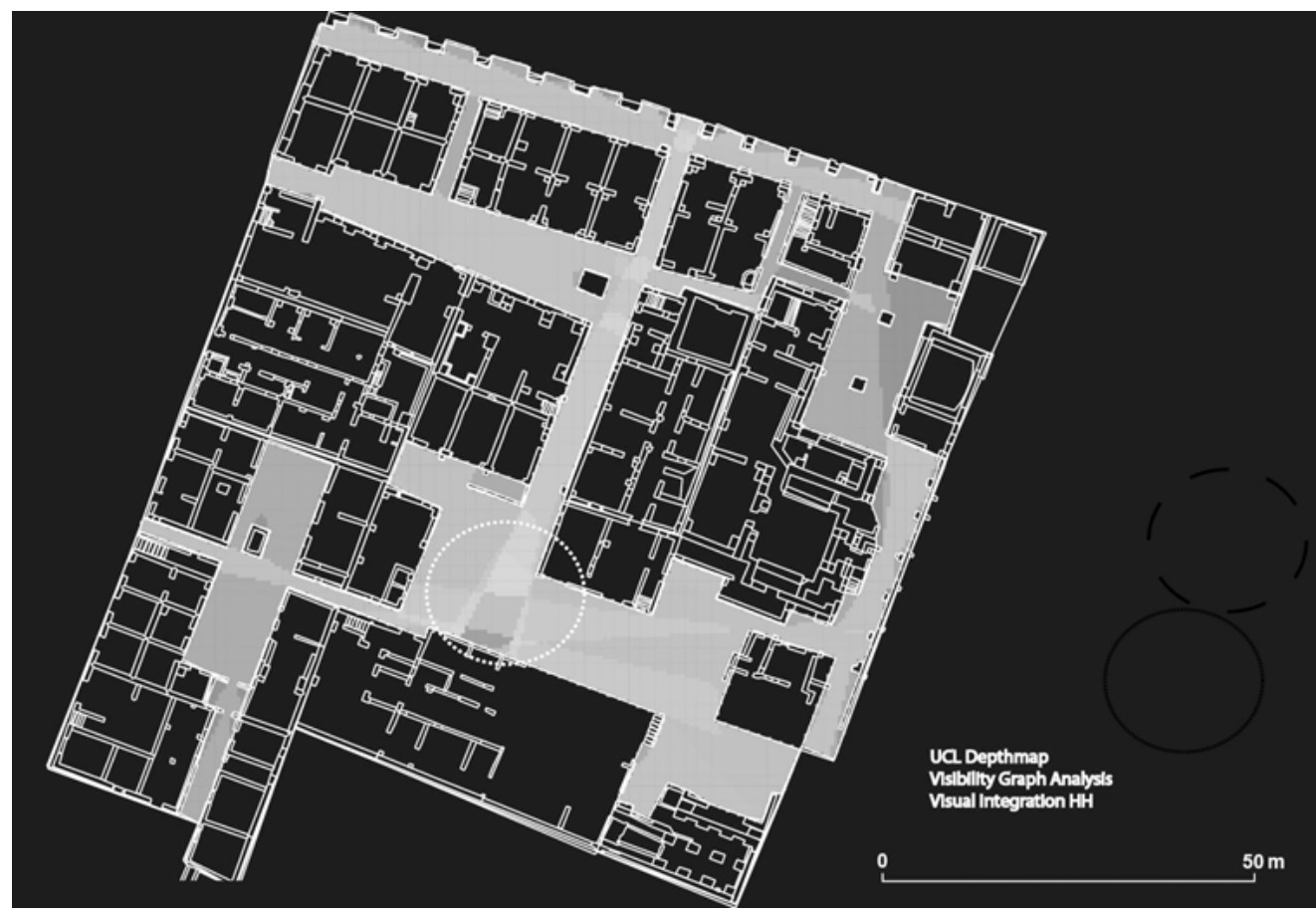

Figure 8 | VGA identifies the southern courtyard as the visually most integrated space (marked by a circle).

most neighbouring insulae, as can be seen in the development of the Late Roman domus, which affected other Ostian insulae during the late Roman period.

This case study of Ostia's Insula IV ii has demonstrated that syntactic and visual tools of spatial analysis can add a valuable dimension to the archaeological assessment of a past built environment. Spatial and visual patterns have been identified which would otherwise not be open to visual inspection by the archaeologists studying the buildings. The real advantage of Space Syntax lies in the fact that the method forces the researcher to understand a building or a group of buildings as a configuration of space, whereby Space Syntax becomes a tool to think with. Since the method is intuitive, it inspires the researcher to experiment at various levels: the technical side of the analyses and the possible interpretations of the results. The syntactic enquiry into the Insula should be further expanded to include various other spatial parameters, such as examining the Insula's total configuration from the perspective of each individual building, or exploring the Insula's visual fields from location to location. Another promising addition to the current analysis should include the streets of the Insula's immediate surroundings into the area defined for analysis. This would give the Insula a buffer zone to counteract possible edge effects, which the immediate boundary of the Insula might exert on the analysis. Moreover, by including a certain amount of street space the effect of the streets on the Insula could be calculated and evalu- 


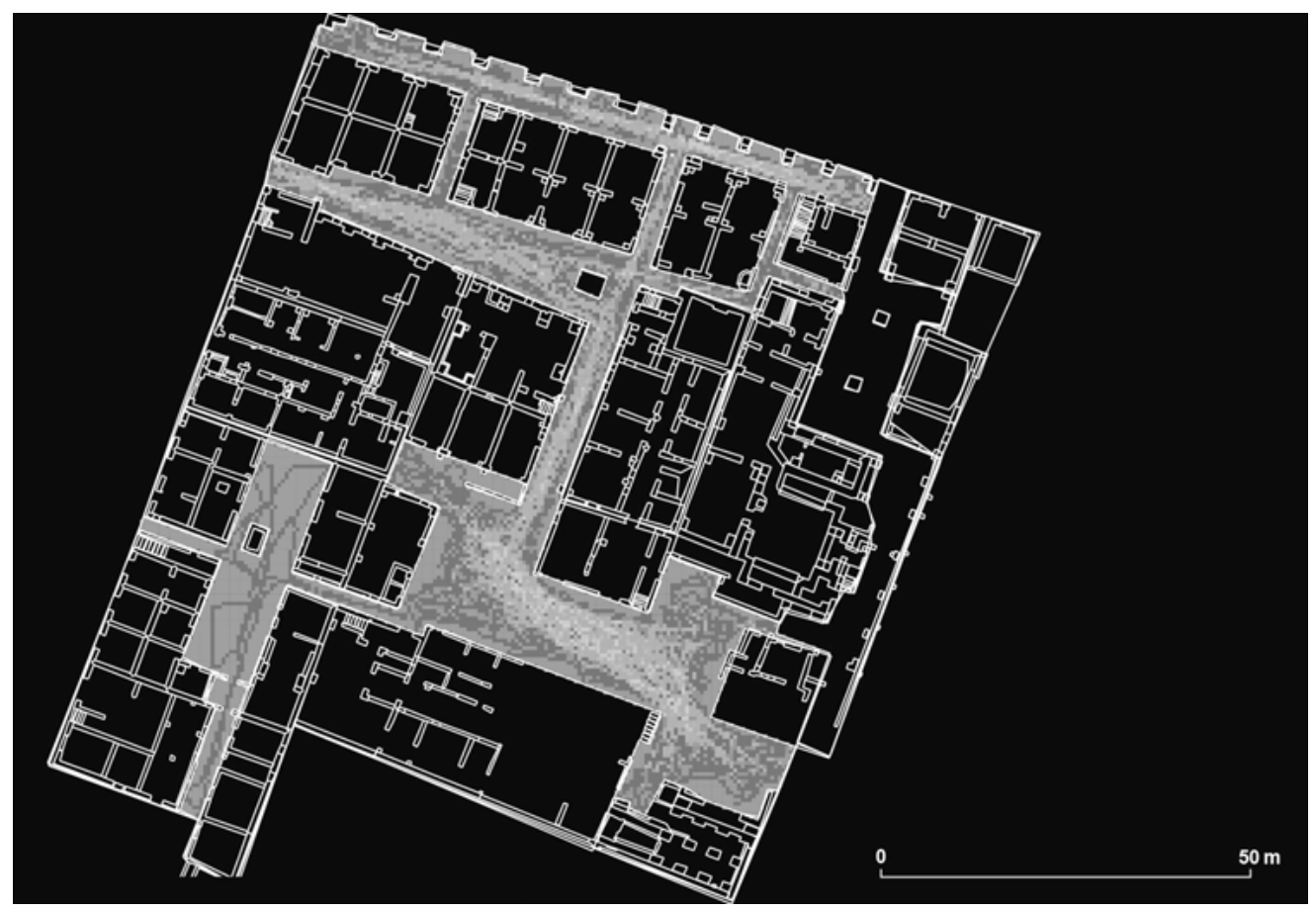

Figure 9 | Agent analysis (preliminary state) movement traces of 50 autonomous agents concentrated in the southern courtyard.

ated. This would no doubt lead to yet another set of questions related to the position of the Insula within the spatial configuration of the entire city and would require a wider analysis of the neighbourhood and the city's street network.

\section{Bibliographical references}

Bauers, Nicoline (200I)

“Die Insulae 'dell'Ercole bambino' und 'del soffitto dipinto' in Ostia”, in: Bericht über die 41. Tagung für Ausgrabungswissenschaft und Bauforschung, Berlin 2000, pp. 67-73.

Bert Lott, John (2004)

The Neighbourhoods of Augustan Rome, Cambridge.

Boersma, Johannes S. (1985)

Amoenissima Civitas: Block Vii at Ostia: Description and Analysis of its Visible Remains, Assen.

\section{Cutting, Marion (2003)}

"The Use of Spatial Analysis to Study Prehistoric Settlement Architecture", in: Oxford Jounal of Archaeology 22, I, pp. I-2I. 
Davis, Howard (2009)

"The Commercial-Residential Building and Local Urban Form", in: Urban Morphology I3, 2, pp. 89-104.

DeLaine, Janet (1999)

"High Status Insula Apartments in Early Imperial Ostia - A Reading", in: S. Mols and C. van der Laan (eds.), Mededelingen van het Nederlands Instituut te Rome: Antiquity, Nederlands Instituut te Rome, pp. 175-89.

DeLaine, Janet (2004)

“Designing for a Market: 'Medianum' Apartments at Ostia”, in: Journal of Roman Archaeology I7, pp. $147-$ I76.

Fisher, Kevin. D. (2006)

"Messages in Stone: Constructing Socio-Political Inequality in Late Bronze Age Cyprus", in: E. C. Robertson, J. D. Seibert, D. C. Fernandez, and M. U. Zender (eds.), Space and Spatial Analysis in Archaeolog, Calgary, pp. I23-I3I.

Gering, Axel (2002)

"Die Case a Giardino als unerfüllter Architektentraum: Planung und gewandelte Nutzung einer Luxuswohnanlage im antiken Ostia", in: Mitteilungen des Deutschen Archäologischen Instituts, Römische Abteilung I09, pp. Iо9-I40.

Gering, Axel (2004)

"Plätze und Straßensperren an Promenaden: Zum Funktionswandel Ostias in der Spätantike", in: Mitteilungen des Deutschen Archäologischen Instituts, Römische Abteilung III, pp. 299-382.

Grahame, Mark (2000)

Reading Space: Social Interaction and Identity in the Houses of Roman Pompeii: A Syntactical Approach to the Analysis and Interpretation of Built Space, Oxford.

Hanson, Julienne (1998)

Decoding Homes and Houses, Cambridge.

Heinzelmann, Michael (2002)

"Bauboom und urbanistische Defizite - zur städtebaulichen Entwicklung Ostias im 2. Jh.", in: C. Bruun and A. Gallina Zevi (eds.), Ostia e Portus: Nelle Loro Relazioni con Roma, Rome, pp. IO3-I2I.

Heinzelmann, Michael (2005)

"Die vermietete Stadt", in: P. Zanker and R. Neudecker (eds.), Lebenswelten: Bilder und Räume in der römischen Stadt der Kaiserzeit, Palilia I6, pp. II3-I28.

Hillier, Bill (2007, $\mathbf{I}^{\text {st }}$ edition 1996$)$

Space is the Machine, Cambridge.

Hillier, Bill, and Hanson, Julienne (1984)

The Social Logic of Space, Cambridge, New York.

Hillier, Bill, and Vaughan Laura (2007)

"The City as One Thing", in: Progress in Planning: Special Issue on The Syntax of Segregation, Edited by Laura Vaughan 67, 3, pp. 205-230. 
Jones, Rick, and Robinson, Damian (2007)

"Intensification, Heterogeneity and Power in the Development of Insula VI, I", in: J. J. Dobbins and J. E. Foss (eds.), The World of Pompeii, London, New York, pp. II9-I28.

\section{Kockel, Valentin (200I)}

"Il palazzo per tutti' La découverte des immeubles locatifs de l'Antiquité et son influence sur l'architecture de la Rome fasciste", in: J.-P. Descoeudres (ed.), Ostia. Port et porte de la Rome antique, Genève, pp. 66-73.

Laurence, Ray (2007, $2^{\text {nd }}$ edition)

Roman Pompeii: Space and Society, London, New York.

Meiggs, Russel (1973)

Roman Ostia, Oxford.

Packer, James E. (I97I)

"The Insulae of Imperial Ostia", Memoirs of the American Academy in Rome, Rome.

Pasini, Francesca (1978)

Ostia Antica. Insule e classi sociali, Rome.

Pavolini, Carlo (2002)

"La trasformazione del ruolo di Ostia nel III secolo D.C.", in: MEFRA II4, I, pp. 325-352.

\section{Scagliarini Corlàita, Daniela (1995)}

"La grande insulae di Ostia come integrazione tra edilizia residenziale e infrastrutture urbane”, in: G. Cavalieri Manasse and E. Roffia (eds.), Splendida Civitas Nostra: studi archeologici in onore di Antonio Frova, Studi e ricerche sulla Gallia Cisalpina, pp. I7I-I8I.

Smith, Michael E. (2010)

"The Archaeological Study of Neighborhoods and Districts in Ancient Cities", Journal of Anthropological Archaeology, 29.2, pp. 137-I54.

\section{Steuernagel, Dirk (200I)}

"Kult und Community: Sacella in den Insulae von Ostia", in: Mitteilungen des Deutschen Archäologischen Instituts, Römische Abteilung 108, pp. 4I-56.

\section{Stöger, Hanna (2007)}

"Roman Ostia: Space Syntax and the Domestication of Space", in: A. Posluschny, K. Lambers, and I. Herzog (eds.), Layers of Perception, Proceedings of the 35th International Conference on Computer Applications and Quantitative Methods in Archaeology (CAA), Berlin, pp. 322-327.

\section{Stöger, Hanna (20II)}

Rethinking Ostia: A Spatial Enquiry into the Urban Society of Rome's Imperial Port-Town, Archaeological Studies Leiden University 24, Leiden.

Thaler, Ulrich (2005)

"Narrative and Syntax: New Perspectives on the Late Bronze Age palace of Pylos, Greece", in: A. v. Nes (ed.), 5th International Space Syntax Symposium, Proceedings, Delft, pp. 323-339. 
Turner, A., Doxa, M., O'Sullivan, D., and Penn, A. (200I)

"From Isovists to Visibility Graphs: A Methodology for the Analysis of Architectural Space", in: Environment and Planning B: Planning and Design 28, pp. I03-I2I.

Vaughan, Laura, Jones, Kate, Griffith, Sam, and Mordechai, Haklay (eds.) (2009)

“The Spatial Signature of Suburban 'Active' Centres'”, in: D. Koch, L. Marcus, and J. Steen (eds.), 17th International Space Syntax Symposium, Stockholm, pp. I27.I-I27.I3.

\section{Ynnilä, Heini (20II)}

"Meaningful Insula: Bridging the Gap between Large and Small Case Studies of Urban Living Conditions", in: D. Mladenovic and B. Russel (eds.), TRAC 2010. Proceedings of the Twentieth Annual Theoretical Roman Archaeology Conference, Oxford 2010, Oxford, Oaksville, pp. $47-58$. 
